\title{
Investigation of the Granulometric and Mechanical Properties of Inorganic Used Sand
}

\author{
V. DARGAI ${ }^{1}$, L. VARGA $^{2}$ \\ ${ }^{1}$ University of Miskolc, Faculty of Material Science and Engineering, Institute of Metallurgical and Foundry \\ Engineering, viktoria.dargai@gmail.com \\ 2University of Miskolc, Faculty of Material Science and Engineering, Institute of Metallurgical and Foundry \\ Engineering, ontvlaci@uni-miskolc.hu
}

Abstract. This paper examines the use of a modified inorganic binder in metal-alloy casting. The results of investigations regarding the effect of reusing the used sand multiple times without reclamation. The technological properties of silica sand with inorganic binders were presented, two different temperatures were applied to make the used sands. After lump crushing the inorganic used sand was recycled in order to make a new sand mixture. Our work was focused on the effect of multiple usage of inorganic used sands on the mechanical and granulometric properties prepared with modified inorganic binder.

\section{Introduction}

Nowadays foundry technologies are the main users of quartz sand, which is used as the base material of moulding and core making. Traditional sand technologies are still dominating all other foundry processes so much, that about $80 \%$ of the castings made worldwide are performed by this method [1] In recent years, foundry technologies have strongly developed, but they are still applying quartz sand as the main material for core production. Therefore, the application and reusability of sand plays an important role in the foundry world. The other major factor is the ever stricter environmental and health laws. These changes negatively affect the cost of depositing the used sand and the reclaimed sand as the procedures are becoming more and more expensive. Foundries are trying to recycle the used sand in the sand circuit system in order to save costs, thus in most cases, the used sand will be reclaimed. Reclamation of used sands can be defined as a conversion process of foundry sands into a moulding material which properties similar to new sand, by removing the residual binder. [2], [3] Generally applied reclamation processes are used practically for all foundry sands, but the reclamation is not always successful, especially when the binder materials are inorganic. The use of inorganic binders has been increased significantly in recent decades, because it is less harmful to the environment and health, due to zero emission and there is no unpleasant odour occurring during core production and casting.

Hydrated sodium silicate (water glass) is one of the most popular and commonly applied inorganic binder. [4] Water glass is not considered as a standard compound but its a collective term for various alkali-silicate melts and compounds that forms a glassy solid. The alkali salts of silica are also 
considered water glass. Water glass can be characterised with its module ( $\mathrm{SiO}_{2}: \mathrm{Na}_{2} \mathrm{O}$ ratio), density and viscosity [2]. Inorganic binders have been successfully used as binders for various manufacturing processes in the past. Especially water glass- $\mathrm{CO}_{2}$ and water glass- ester methods, which are considered classic inorganic core-production technologies. During their application various chemical processes are responsible for hardening phenomenon. Cores produced with these methods are not suitable for the modern market, because of their low strength, yield properties, knock-out ability and the limited reusability of the regenerated materials. New inorganic binder systems have been developed during the last 15 years, due to the new manufacturing processes and the developments in silicate chemistry. Chemical binding and drying are combined in most of the newly developed inorganic water glass based binding processes. The two main components of such systems are a liquid modified water glass binder and a powder-based additive [2], [5]. Inorganic binders can be used mostly for aluminium castings because of the low casting temperature. However, foundries are carrying out researches of their successful application for iron casting production [6]

\section{Materials and methodology of the research}

The aim of presented research was to determine the mechanical and granulometric properties of inorganic used sand. The inorganic used sand was recycled in multiple rounds using the same sand mixture recipe. As research materials, a Slovakian 3-components quartz sand and a modified inorganic binder were used. The applied amount of binder for each recycled round was $2,2 \mathrm{~m} / \mathrm{m} \%$. The used sand was thermal loaded at $150^{\circ} \mathrm{C}$ and $600^{\circ} \mathrm{C}$ for one hour. After lump crushing, the used sand was recycled for making the new mixture from which the new test piece was created.

The bending samples were produced using Multiserw Universal Core Shooter laboratory machine. Table 1 shows the production parameters for bending samples.

\begin{tabular}{|l|c|}
\hline Core box temperature & $180^{\circ} \mathrm{C}$ \\
\hline Gassing temperature & $100^{\circ} \mathrm{C}$ \\
\hline Shoot pressure & $3 \mathrm{bar}$ \\
\hline Gassing time & $30 \mathrm{~s}$ \\
\hline
\end{tabular}

The bending samples were measured with Multiserw Universal Strength Testing Machine. The following mechanical properties were measured:

- immediate strength

- strength after 1 hour

- residual strength after the thermal load.

Figure 1 shows the used strength testing machine. 


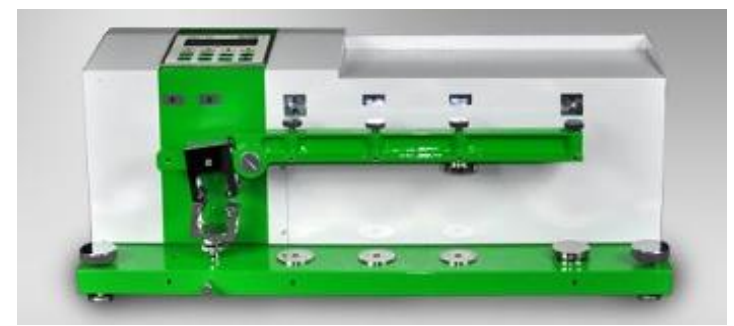

Figure 1. Universal Strength Testing Machine [7]

Sieve analysis was made for every recycled round with Fritsch Analysette 3 Pro sieve shaker, shown in Figure 2.

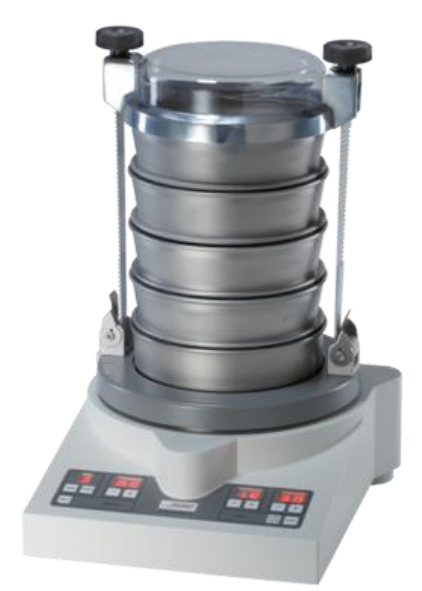

Figure 2. Fritsch Analysette 3 Pro sieve shaker [8]

\section{Results of laboratory test}

\subsection{Sieve analysis}

During the research, the granulometric properties of the recycled used sand were investigated after every cycle. The applied sand is a 3-component quartz sand, which composition does not change when recycled. However, the grain size distribution has changed as result of the recycling. Figure 3 shows the granulometric properties of thermal loaded used sands at $150^{\circ} \mathrm{C}$. 
International Journal of Engineering and Management Sciences (IJEMS) Vol. 5. (2020). No. 2

DOI: 10.21791/IJEMS.2020.2.34.

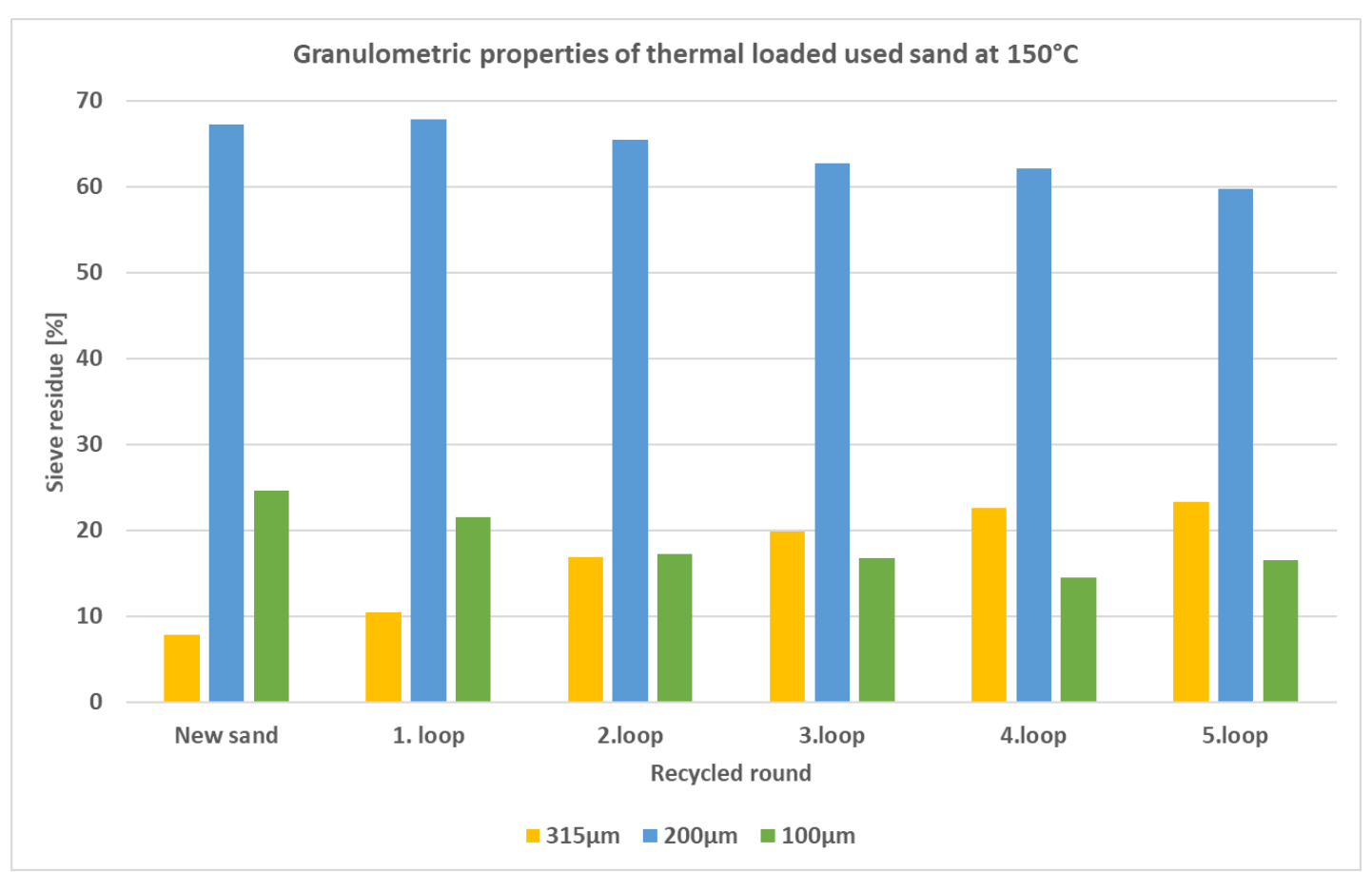

Figure 3. Sieve analysis of thermal loaded used sand at $150^{\circ} \mathrm{C}$

Figure 3 shows that the amount of $315 \mu \mathrm{m}$ grain fraction steadily increases due to the recycling and by 5 th loop it accumulates up to $300 \%$. The amount of $200 \mu \mathrm{m}$ grain fraction decreased due to the recycling loops. For the 5th loop, the amount of grain fraction is reduced by $11 \%$. The amount of $100 \mu \mathrm{m}$ grain fraction also decreased during the recycling loops compared to the new sand.

Figure 4 shows the granulometric properties of thermal loaded used sands at $600^{\circ} \mathrm{C}$.

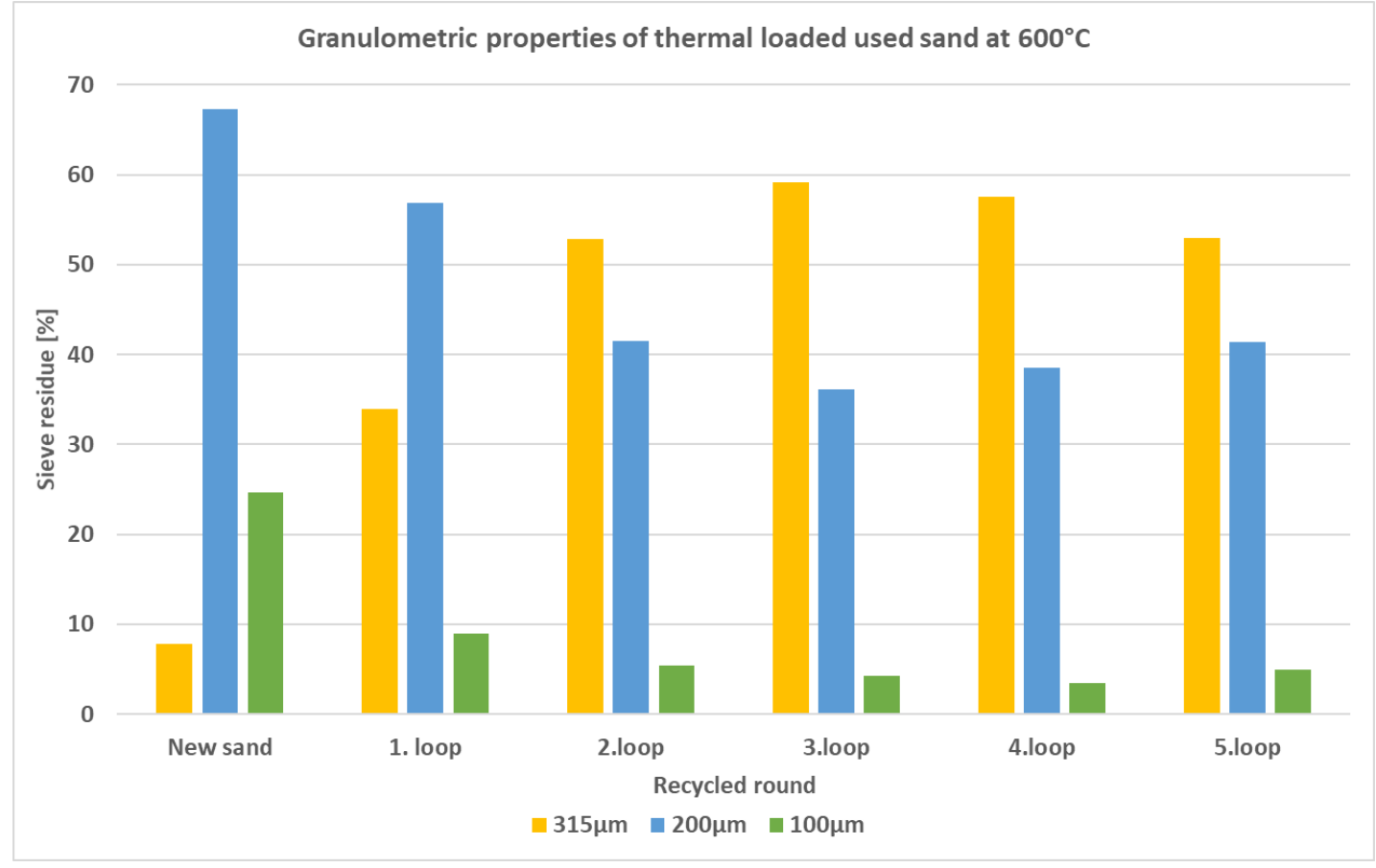

Figure 4. Sieve analysis of thermal loaded used sand at $600^{\circ} \mathrm{C}$ 
In Figure 4 represents an increase in the $315 \mu \mathrm{m}$ grain fraction yet again and by 5 th loop this accumulates to $670 \%$. The amount of $200 \mu \mathrm{m}$ and $100 \mu \mathrm{m}$ grain fraction decreased during the recycle process compared to the new sand.

\subsection{Bending strength}

The bending strength of the recycled used sand were investigated after each cycle. These values, after being thermal loaded at $150^{\circ} \mathrm{C}$ for an hour, are shown in Figure 5 .

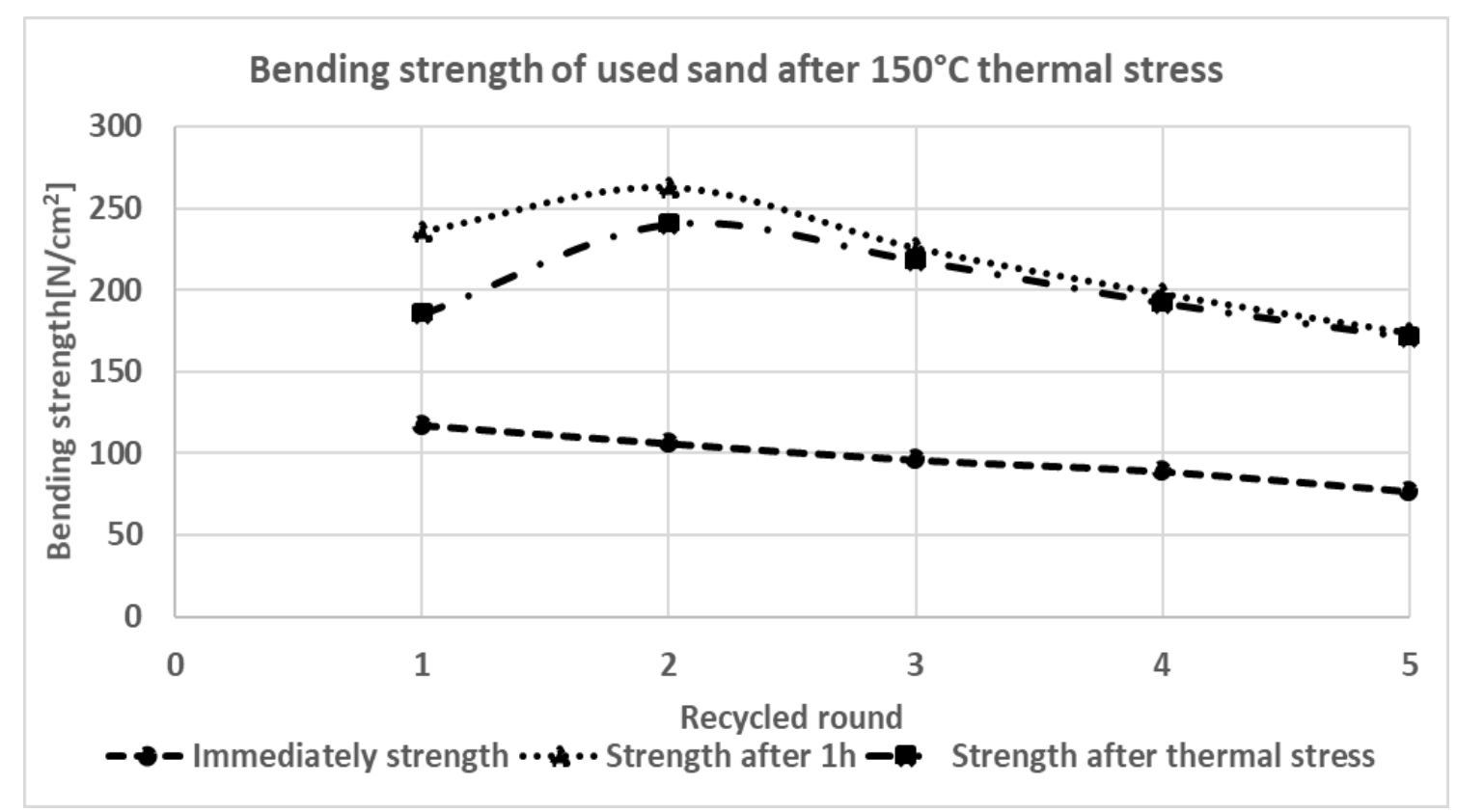

Figure 5. Bending strength of thermal loaded used sand at $150^{\circ} \mathrm{C}$

Figure 5 shows a linear decrease in the immediate strength. Strength after 1 hour increased by $10 \%$ over the initial strength value in the second loop. This initial increase, starting with the third loop, starts to decrease as well, taking a linear reduction value. This reduction reaches a total of $30 \%$ in bending strength for loop 5th. As for the residual strength value, it increased after the second loop by $30 \%$, after that strength decreased as well.

Figure 6 shows the bending strength results of thermal loaded used sand at $600^{\circ} \mathrm{C}$. 
International Journal of Engineering and Management Sciences (IJEMS) Vol. 5. (2020). No. 2

DOI: 10.21791/IJEMS.2020.2.34.

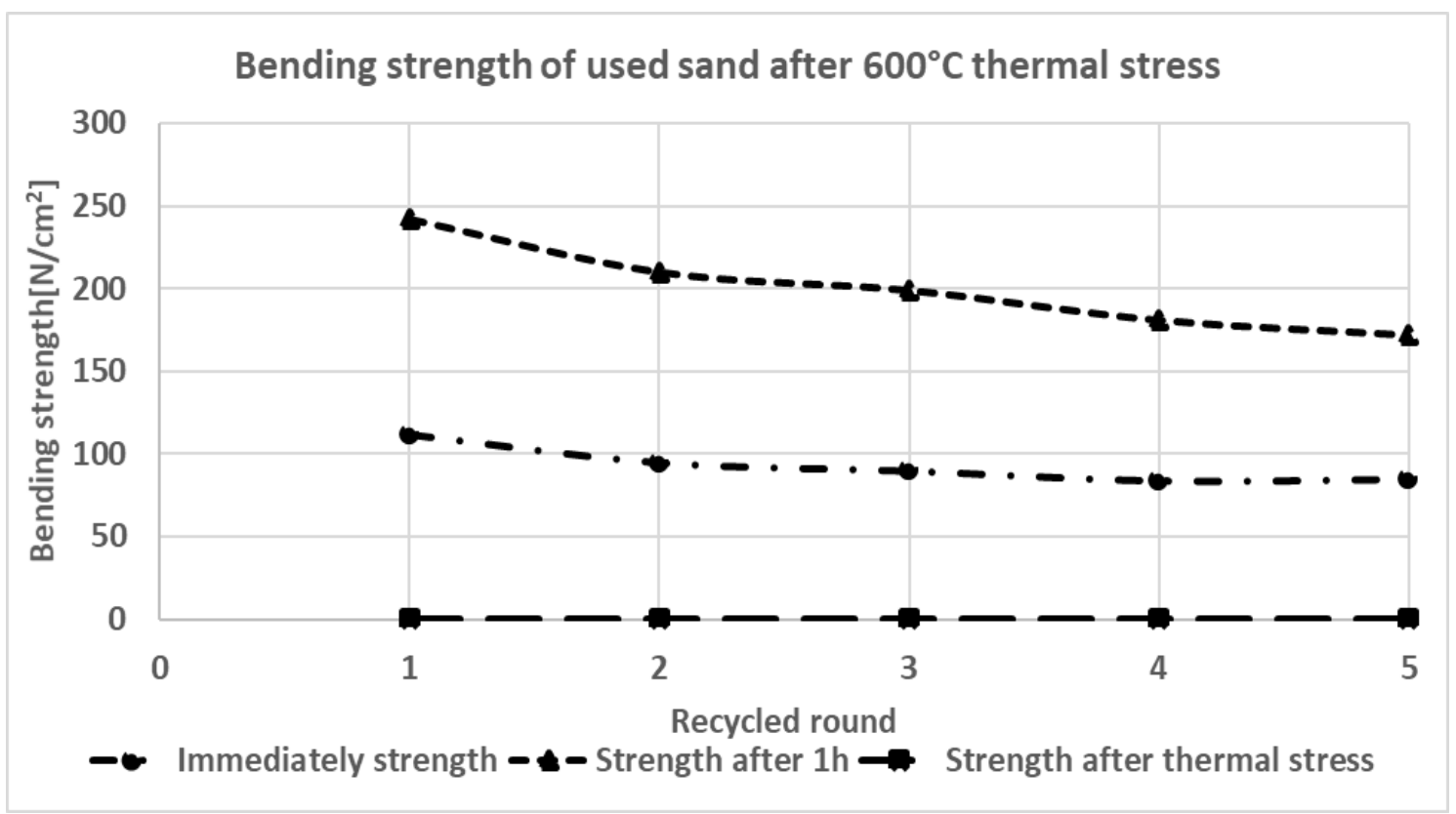

Figure 6. Bending strength of thermal loaded used sand at $600^{\circ} \mathrm{C}$

In Figure 6 the immediate strength also reduces by recycling, but there is no difference between the fourth and fifth loops. Values of strength after 1 hour decreased as well. Residual strength of bending samples was zero for each loop. The samples were unfitted to be measured.

\section{Summary}

Based on the sieve analysis, it was found that the grain fraction of the used sands shifted towards the coarse grain fraction due to the recycling. The extent of the shift depended on thermal load temperature and number of recycling loops. The reason behind the appearance of coarse fraction is the formation of agglomerates.

During the recycling, the immediate strength values have decreased at both $150^{\circ} \mathrm{C}$ and $600^{\circ} \mathrm{C}$ for thermal loaded used sands. Strength after 1 hour of thermal loaded used sands at $150^{\circ} \mathrm{C}$ increased in the second loop, then it started to decline. In case of thermal loaded used sand at $600^{\circ} \mathrm{C}$ during the recycling, values of strength after 1 hour decreased. For thermal loaded used sand at $150^{\circ} \mathrm{C}$, the residual strength value for the second loop increased and then bending strength values decreased. At $600^{\circ} \mathrm{C}$ no residual strength can be measured. The decrease in strength values occurred due to changes in grain sizes of used sand.

\section{References}

[1] J. Danko, R. Danko, M. Holtzer, Reclamation of used sands in foundry production, Metalurgija 42 (3), 173-177

[2] H. Polzin, Anorganische Binder zur Form- und Kernherstellung in der Giesserei, Fachverlag Schiele und Schön GmbH 
International Journal of Engineering and Management Sciences (IJEMS) Vol. 5. (2020). No. 2

DOI: 10.21791/IJEMS.2020.2.34.

[3] J. Danko, M. Holtzer, Factors influencing selection of effective reclamation techniques and assessment methods of the reclaimed material quality, Archives of Foundry Engineering Volume 7 (4), 29-32

[4] I. Izdebska-Szanda, J. Kaminska, M. Angrecki, A. Palma, Z. Stefanski, The Effect of Additive "B" on the Properties of Foundry Sands with Hydrated Sodium Silicate Made by Floster Technologie, Archives of Foundry Engineering Volume 17, 31-34

[5] L. Tóth, Forma és magkészítési ismeretek, oktatási segédlet, 2011.

[6] C. Wallenhorst, Chemische Grundlagen der Anorganischen Bindemittel-Betrachtung der Kernherstellung auf molekularer Ebene, Gießerei-Rundschau 57., 50-52

[7] http://multiserw-morek.pl/en/products,core_and_molding_sand_testing_equipment-1

[8] https://www.fritsch-international.com/sample-preparation/sieving/vibratory-sieveshakers/details/product/analysette-3-pro/ 